\title{
Moso bamboo (Phyllostachys edulis (Carriere) J. Houzeau) invasion affects soil phosphorus dynamics in adjacent coniferous forests in subtropical China
}

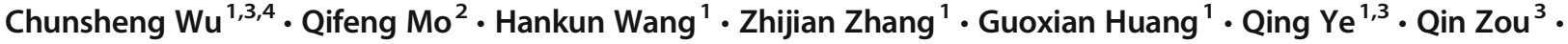 \\ Fanqian Kong ${ }^{3} \cdot$ Yuanqiu Liu ${ }^{1,3} \cdot$ G. Geoff Wang ${ }^{1,4}$
}

Received: 19 September 2017 / Accepted: 29 January 2018 / Published online: 27 February 2018

(C) INRA and Springer-Verlag France SAS, part of Springer Nature 2018

\begin{abstract}
- Key message The invasion of moso bamboo (Phyllostachys edulis (Carriere) J. Houzeau) into neighboring Cryptomeria japonica (L. f.) D. Don plantations significantly altered soil P status and dynamics. This alteration in phosphorus dynamics must be considered when assessing the ecological consequence of moso bamboo invasion in subtropical China.

- Context Moso bamboo is a native species that commonly invades into adjacent forests in Asia. Such invasions may significantly alter soil chemical characteristics because moso bamboo has very different traits compared with the tree species it displaces. However, few studies have investigated the effects of moso bamboo invasion on soil phosphorus (P) dynamics.

- Aims The objective of this study was to investigate the effects of moso bamboo invasion on soil P dynamics. Specifically, we quantified soil total P, available P, acid phosphatase activity (APA), and microbial biomass P (MBP) in moso bamboo-invaded coniferous stands and compared them to uninvaded stands and pure moso bamboo stands.

- Methods We compared seasonal dynamics of soil P (e.g., total P, available P, APA, and MBP) over a 24-month period among three stand types at Lushan mountain in subtropical China: Cryptomeria japonica plantation (CR), Cryptomeria japonica plantation invaded by Phyllostachys edulis (PH-CR), and Phyllostachys edulis stand (PH).

- Results Total soil P concentration was significantly lower in PH-CR than in CR and PH stands, but soil available P concentration was significantly lower in CR and PH stands. Soil APA was significantly higher in PH-CR than in CR and PH stands. Similarly, soil MBP concentration was higher in PH-CR than in CR and PH stands. Also, soil total P, available P, APA, and MBP concentrations displayed seasonal fluctuations in PH-CR, but remained relatively stable in CR and PH stands during the 2 years. - Conclusion The invasion of moso bamboo into adjacent $C$. japonica stands significantly increased soil available $\mathrm{P}$, acid phosphatase activity, and microbial biomass phosphorus, but decreased soil total P. The implication of these changes to ecosystem composition, structure, and function must be explicitly considered in managing moso bamboo invasion in subtropical China.
\end{abstract}

Handling Editor: Andreas Bolte

Contribution of the co-authors The authors contributed equally to investigate, collect data, and complete the project. C.S.W., Q.F.M., Z.J.Z., H.K.W., G.X.H., C.J.S., Q.Z., F.Q.K., Q.Y., Y.Q.L, and G.G.W. were responsible for the research design and wrote early drafts of the manuscript. C.S.W., Q.F.M., Y.Q.L., and G.G.W substantially contributed to interpreting and revising the manuscript.

\section{Yuanqiu Liu}

liuyq404@163.com

G. Geoff Wang

gwang@clemson.edu

1 Key Laboratory of Silviculture, Co-Innovation Center of Jiangxi Typical Trees Cultivation and Utilization, College of Forestry, Jiangxi Agricultural University, Zhimin Rd. 1101, Nanchang 330045, People's Republic of China
2 College of Forestry and Landscape Architecture, South China Agricultural University, Wushan Rd. 483, Tianhe District, Guangzhou 510642, China

3 Lushan Nature Reserve of Jiangxi (Lushan Mountain National Forest Ecological Station), Henan Rd. 600, Jiujiang 332900, People's Republic of China

4 Department of Forestry and Environmental Conservation, Clemson University, Clemson, SC 29634, USA 
Keywords Moso bamboo invasion - Soil phosphorus dynamics · Cryptomeria japonica forest - Ecosystem composition . Subtropical China

\section{Introduction}

Moso bamboo (Phyllostachys edulis) is widely distributed in subtropical China (Wang et al. 2013). Because of its typical clonal propagation, moso bamboo often spreads into the adjacent communities due to the extension of its underground rhizomes (Wang et al. 2016a). Over the last decades, the invasion of moso bamboo into adjacent forests has frequently been reported, particularly in the nature reserves where the harvesting of moso bamboo is prohibited (Zhang et al. 2010; Bai et al. 2016; Li et al. 2017a). As a result, several recent studies have regarded moso bamboo as a potentially invasive species in the subtropical regions (Mertens et al. 2008; Song et al. 2016; Ying et al. 2016; Li et al., 2017b).

Unconstrained, moso bamboo invasions may significantly alter the composition, structure, and function of the impacted forest ecosystems. Because of its clonal reproduction, moso bamboo can quickly form a monoculture and displace other tree species (Suzuki. 2015). In addition, recent studies have also reported that moso bamboo invasion affected physical, chemical, and biological soil properties (Lin et al. 2014; Fukushima et al. 2015; Shinohara and Otsuki 2015; Chang and Chiu 2015; Xu et al. 2015; Wang et al. 2016b; Song et al. 2017; Li et al. 2017a; Qin et al. 2017; Shiau and Chiu 2017).

Most studies on the effect of moso bamboo invasion focused on the soil $\mathrm{C}$ and nitrogen $(\mathrm{N})$ dynamics in the forests invaded by moso bamboo. Bai et al. (2016) reported that moso bamboo encroachment into evergreen broad-leaved forests not only substantially altered soil $\mathrm{C}$ and $\mathrm{N}$ pools but also changed the distribution pattern of $\mathrm{C}$ and $\mathrm{N}$; Song et al. (2016) found that the expansion of bamboo (Phyllostachys heterocycla (Carr.) Mitford cv.) into neighboring evergreen broad-leaved forests reduced soil $\mathrm{N}$ mineralization rate. In addition to $\mathrm{C}$ and $\mathrm{N}$, previous studies also reported the effects of bamboo invasions on other soil nutrients. Umemura and Takenaka (2015) indicated that the soil exchangeable Ca, K, and $\mathrm{Mg}$ contents in the hinoki cypress (Chamaecyparis obtusa Sieb. et Zucc.) forests showed significant differences after the invasion by moso bamboo. Ikegami et al. (2014) found that when non-bamboo forests were expanded and dominated by bamboo species, the available silica concentration in the surface soil was significantly increased. To our knowledge, however, no studies have ever examined the effects of moso bamboo on soil phosphorus (P) dynamics.

In subtropical China, $\mathrm{P}$ is often the most limiting nutrient (Elser et al. 2007), and P availability may become even more limiting due to the increasing atmospheric $\mathrm{N}$ deposition (Liu et al. 2011; Deng et al. 2016). Furthermore, the altered $\mathrm{C}$ and $\mathrm{N}$ dynamics due to moso bamboo invasion could also have significant implications for $\mathrm{P}$ availability. Currently, many Cryptomeria japonica plantations at Lushan Mountain Nature Reserve have been invaded by moso bamboo, which significantly affected soil $\mathrm{N}$ dynamics ( $\mathrm{Li}$ et al. 2017a). These plantations have also faced many problems, including low species diversity, simplified structure (monoculture with a poorly developed shrub and herb layer), and poor resistance to natural disturbances. Therefore, the objective of this study was to investigate how moso bamboo invasion into $C$. japonica plantation affected soil $\mathrm{P}$ dynamics. Specifically, we quantified total $\mathrm{P}$, available $\mathrm{P}$, acid phosphatase activity (APA), and microbial soil biomass P (MBP) and their seasonal patterns in invaded $C$. japonica stands and compared them to uninvaded stands and pure moso bamboo stands. We hypothesized that the invasion of moso bamboo into $C$. japonica stands would increase available $\mathrm{P}$ concentration, soil APA, and MBP concentration but decrease total soil $\mathrm{P}$ concentration.

\section{Materials and methods}

\subsection{Study area}

This study was conducted at Lushan Mountain Nature Reserve in Jiangxi Province of China $\left(29^{\circ} 31^{\prime} \sim 29^{\circ} 41^{\prime} \mathrm{N}\right.$, $\left.115^{\circ} 51^{\prime} \sim 116^{\circ} 07^{\prime} \mathrm{E}\right)$. The study area is characterized by a subtropical monsoon climate. The annual mean temperature is $12.4{ }^{\circ} \mathrm{C}$, and annual mean precipitation is $2587 \mathrm{~mm}$ during the study period. June is the warmest month with a mean temperature of $21^{\circ} \mathrm{C}$, while January is the coldest month with a mean temperature of $1.4{ }^{\circ} \mathrm{C}$. The monthly rainfall and air temperature during the study period are given in Fig. 1.

Situated in the center of the vast plain of the middle and lower reaches of the Yangtze River, Lushan mountain is an isolated mountain body that covers an area of about $300 \mathrm{~km}^{2}$, ranging from 30 to $1474 \mathrm{~m}$ a.s.l. According to the FAO soil texture classification, soil types in Lushan change from ferric alisols at low elevations to haplic alisols at high ones (Liu and Wang. 2010). Evergreen forests are dominated by several Fagaceae tree species at the low altitudes (50-600 m a.s.l), and some evergreen woodland species and shrubs. Deciduous trees grow at the elevation of 600-1000 m a.s.l., where extensive $C$. japonica plantations were also established about 50 years ago (Liu and Wang. 2010). 
Fig. 1 Average monthly rainfall and air temperature during 2015.11-2016.10 in Lushan Mountain, China. N, D, J... represents the abbreviation for each month (From November 2014 to October 2016 (24 months in total))

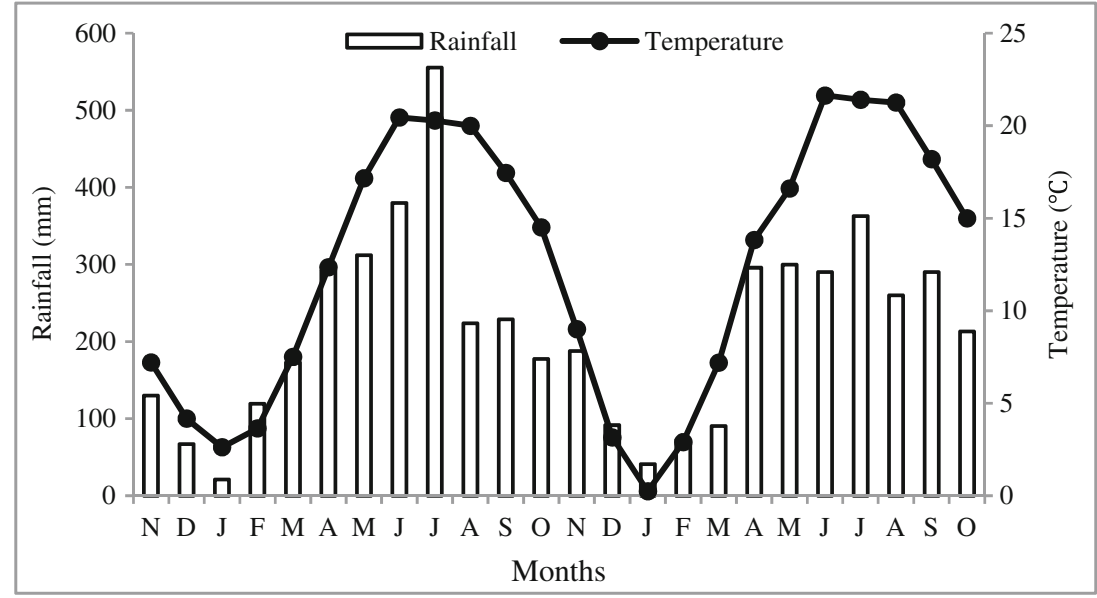

\subsection{Sampling design}

This study was conducted based on Forestry Standards "Observation Methodology for Long-term Forest Ecosystem Research" of the People's Republic of China (LY/T 19522011). We sampled three forests, each consisted of three stand types: pure Cryptomeria japonica (CR), mixed Phyllostachys edulis-Cryptomeria japonica (PH-CR), and pure Phyllostachys edulis $(\mathrm{PH})$ stand. As a result, a total of nine plots were sampled. The three CR plots were planted in 1950 while the three $\mathrm{PH}$ plots were of natural origin. The three $\mathrm{PH}-$ CR plots resulted from the invasion of Phyllostachys edulis into adjacent Cryptomeria japonica stands, and currently had an even mixture of both species. In each sampled forest, one $20 \times 20 \mathrm{~m}$ plot was established within each stand type in November 2014, and all three sampled plots in each forest had a similar slope, aspect, and slope position.

\subsection{Data collection}

Soil samples were collected every month, from November 2014 to October 2016 (24 months in total), to evaluate the temporal changes in soil $\mathrm{P}$ dynamics. On each plot, soil samples from the top layer $(0-20 \mathrm{~cm})$ were collected with a soil auger $(6 \mathrm{~cm}$ diameter $\times 20 \mathrm{~cm}$ height). Five soil cores in each plot were mixed thoroughly then brought back to the lab by an ice-box within $24 \mathrm{~h}$. The litter layer and humus above mineral soil was removed before the soil was taken.

Half of the fresh soils were stored at $4{ }^{\circ} \mathrm{C}$, and used to determine available P, APA, and MBP; the other part of the soil was air dried, and the roots or visible plant residuals were removed. These dried and cleaned soil samples were then finely ground in a ball mill and used to determine total soil P. Soil available $\mathrm{P}$ was extracted using $\mathrm{HCl}-\mathrm{NH}_{4} \mathrm{~F}$ solution and determined by molybdenum-antimony anti-colorimetric assay (Liu. 1996). Soil acid phosphatase activity (APA) was determined using para-nitrophenyl phosphate (p-NPP) as the substrate and a slight modification ( $1 \mathrm{~mL} 2 \mathrm{M}$ calcium chloride $\left(\mathrm{CaCl}_{2}\right)$ and $4 \mathrm{~mL} 0.2 \mathrm{M}$ sodium hydroxide $(\mathrm{NaOH})$ were added to stop the reaction and to extract the p-NP formed) to the original method (Schneider et al. 2000). Microbial biomass P (MBP) was calculated as the difference between $\mathrm{PO}_{4}-\mathrm{P}$ in fumigated and non-fumigated extracts. Extractable $\mathrm{PO}_{4}-\mathrm{P}$ in the fumigated and non-fumigated extracts was determined colorimetrically, using the malachite green method adapted for a plate reader. The extracting solution was $1 \mathrm{M}$ $\mathrm{KCl}(2 \mathrm{~h}), 0.1 \mathrm{M} \mathrm{NaOH}(17 \mathrm{~h})$, and $0.5 \mathrm{M} \mathrm{HCl}(24 \mathrm{~h})$ (D'Angelo et al. 2001). Total soil P concentrations were measured using molybdate-blue reaction (Lu. 1999) with a UV2450 spectrophotometer (Shimadzu Scientific Instruments, Japan). Total soil organic $\mathrm{C}$ was determined using the $\mathrm{K}_{2} \mathrm{Cr}_{2} \mathrm{O}_{7}-\mathrm{H}_{2} \mathrm{SO}_{4}$ digestion method (Nelson and Sommers. 1975). Total soil N was analyzed with the Kjeldahl method (K-370, Buchi Scientific Instruments, Switzerland). Soil available $\mathrm{N}$ (sum of the ammonium nitrogen, nitrate nitrogen, amino acid, and readily hydrolyzed proteins nitrogen) was measured through the oxidation hydrolyzed into ammonia nitrogen, then absorbed by the boric acid solution and determined by sulfuric acid and titration (Liu. 1996). Soil bulk density was determined using a soil core (Lampurlanés and Cantero-Martinez. 2003). Soil $\mathrm{pH}$ was determined with a Mettler-S20P-K pH meter (1: 2.5, $\left.\mathrm{H}_{2} \mathrm{O}\right)$.

The diameter at breast height (DBH) of each stem was measured using a DBH tape (Sharma 2007). The height of each stem was determined by using a Laser altimeter (SNINO-SL-700, USA). Five $5 \mathrm{~m} \times 5 \mathrm{~m}$ sample plots in each $20 \times 20 \mathrm{~m}$ plot were established along the diagonal, and all sample plots were inventoried to determine the height and density of shrubs and herbs (Jia. 2009).

\subsection{Data analysis}

Repeated measures ANOVA was used to test the effects of stand type, month, and their interaction on the total soil $\mathrm{P}$, 
available P, APA, and MBP. We conducted post hoc tests to examine differences among means for significant results. The mean data of each variable for each stand were calculated from the 24 monthly measurements. All data analyses were performed by using SPSS 19.0 (SPSS Inc., Chicago, USA). Results are reported as significant at $p<0.05$.

\section{Results}

\subsection{Stand and soil characteristics}

The average stand density in PH-CR was significantly higher than in CR and PH stands. The average DBH in PH-CR was significantly higher than in $\mathrm{PH}$ stands, while significantly lower than in CR stands (Table 1). The average height in $\mathrm{PH}-\mathrm{CR}$ was significantly higher than in $\mathrm{PH}$ stands, but not significantly lower than in CR stands. Among all soil variables listed in Table 2, only $\mathrm{C}$ and $\mathrm{N}$ concentrations differed among the three stand types. $\mathrm{C}$ and $\mathrm{N}$ concentrations were larger in $\mathrm{PH}-\mathrm{CR}$ than in $\mathrm{PH}$, and $\mathrm{CR}$ stands.

\subsection{Dynamics of soil $\mathbf{P}$ and available $\mathbf{P}$ contents}

Stand type and month affected total soil $\mathrm{P}$ and soil available soil $\mathrm{P}$ concentrations, and there was no interaction between stand type and month for either total soil $\mathrm{P}$ or available soil $\mathrm{P}$ concentration (Fig. 2). The average total soil $\mathrm{P}$ concentration in PH was higher than in CR and PH-CR stands (Table 3). Despite differences in quantity, total soil $\mathrm{P}$ concentration followed a similar seasonal pattern, with the highest value in summer (July) and the lowest value in winter (February 2015 and January 2016) (Fig. 2). During the 2 years, P concentration remained the highest in $\mathrm{PH}$ stands, and the lowest in $\mathrm{PH}-$ CR stands except a few months in growing season (MaySeptember) during the second year.

The average soil available $\mathrm{P}$ concentration in $\mathrm{CR}$ and $\mathrm{PH}$ was lower than that in PH-CR stands (Table 3). Over the 2 years, soil available $\mathrm{P}$ concentration remained the lowest in CR stands, and the highest in PH-CR stands except a few months in the growing season (June-July) during the first year. PH-CR stands also displayed a greater fluctuation in soil available $P$ concentration, with much lower observed values in June and July, when compared to both CR and PH stands. Soil available $\mathrm{P}$ concentration remained relatively stable over the 2 years in CR stands (Fig. 2).

\subsection{Changes of APA and MBP contents}

Stand type and month affected soil APA and MBP concentrations, and there was no interaction between stand type and month (Fig. 3). The average soil APA concentration in PHCR was higher than in PH and CR stands (Table 3). Similarly, the average soil MBP concentration in PH-CR was higher than in $\mathrm{PH}$ and $\mathrm{CR}$ stands (Table 3). Over the 2 years, soil APA and MBP concentration remained highest in PH-CR and the lowest in PH stands (Fig. 3). Despite differences in quantity among different stand types, soil APA and MBP concentrations followed a similar seasonal pattern. The highest MBP values were observed in summer (July) and the lowest in winter (February). The highest APA values were observed in July 2015, 2016 in PH-CR stands, or in June 2015, 2016 in $\mathrm{CR}$ and PH stands, and the lowest APA values were observed in winter (February 2015, 2016) regardless of stand type (Fig. 3).

\section{Discussion}

Numerous studies have recently indicated that the invasion of moso bamboo (P. edulis) into neighboring forests is one of the most serious ecological problems in subtropical China (Bai et al. 2016; Song et al. 2016, 2017). We found that moso bamboo invasion significantly altered soil $\mathrm{P}$ status and dynamics. Although soil total $\mathrm{P}$ and available $\mathrm{P}$ were lower in CR stands when compared to PH stands, the invasion of moso bamboo into the adjacent $\mathrm{CR}$ stands further decreased total $\mathrm{P}$ concentration, but increased available $\mathrm{P}$ concentration. These
Table 1 Characteristics $( \pm$ SE) of the three stand types in Lushan Mountain of subtropical China

\begin{tabular}{llcc}
\hline Stand type $(n=3)$ & Average stand density $\left(\right.$ stems $\left.^{-2}\right)$ & Average DBH $(\mathrm{cm})$ & Average height $(\mathrm{m})$ \\
\hline PH-CR & Stand $2425 \pm 231 \mathrm{a}$ & $13.3 \pm 2.3 \mathrm{a}$ & $10.5 \pm 2.6 \mathrm{a}$ \\
& PH $1175 \pm 184^{\mathrm{A}}$ & $9.2 \pm 1.1^{\mathrm{A}}$ & $8.0 \pm 2.4^{\mathrm{A}}$ \\
& $\mathrm{CR} 1250 \pm 242^{\mathrm{A}}$ & $17.5 \pm 3.5^{\mathrm{A}}$ & $13.0 \pm 4.4^{\mathrm{A}}$ \\
$\mathrm{PH}$ & $1360 \pm 198 \mathrm{~b}^{\mathrm{B}}$ & $8.7 \pm 1.8 \mathrm{~b}^{\mathrm{A}}$ & $8.5 \pm 2.0 \mathrm{~b}^{\mathrm{A}}$ \\
$\mathrm{CR}$ & $1725 \pm 223 \mathrm{c}^{\mathrm{B}}$ & $17.3 \pm 4.1 \mathrm{c}^{\mathrm{A}}$ & $11.5 \pm 3.8 \mathrm{a}^{\mathrm{A}}$ \\
\hline
\end{tabular}

Different lowercase letters indicate significant differences between stand types $(p<0.05)$. Different uppercase letters indicate significant differences in the same tree species between pure and mixed stands $(p<0.05)$

CR Cryptomeria japonica pure forest, PH-CR Phyllostachys edulis-Cryptomeria japonica mixed forest (Cryptomeria japonica invaded by the bamboo), PH Phyllostachys edulis pure forest 
Table 2 The soil $(0-20 \mathrm{~cm})$ physicochemical properties $( \pm \mathrm{SE})$ of three stand types in Lushan Mountain of subtropical China

\begin{tabular}{lllllll}
\hline Stand type $(n=3)$ & $\mathrm{C}\left(\mathrm{g} \mathrm{kg}^{-1}\right)$ & $\mathrm{N}\left(\mathrm{mg} \mathrm{kg}^{-1}\right)$ & Available N $\left(\mathrm{mg} \mathrm{kg}^{-1}\right)$ & PH values & Bulk density $\left(\mathrm{g} \mathrm{cm}^{-3}\right)$ & Soil types \\
\hline CR & $36.02 \pm 3.53 \mathrm{c}$ & $0.96 \pm 0.16 \mathrm{c}$ & $15.59 \pm 2.20 \mathrm{a}$ & $4.73 \pm 0.04 \mathrm{a}$ & $0.86 \pm 0.10 \mathrm{a}$ & Haplic alisols \\
PH-CR & $56.87 \pm 3.17 \mathrm{a}$ & $2.50 \pm 0.24 \mathrm{a}$ & $17.54 \pm 2.13 \mathrm{a}$ & $4.76 \pm 0.05 \mathrm{a}$ & $0.95 \pm 0.09 \mathrm{a}$ & Haplic alisols \\
PH & $45.07 \pm 1.91 \mathrm{~b}$ & $1.87 \pm 0.19 \mathrm{~b}$ & $16.21 \pm 1.95 \mathrm{a}$ & $4.82 \pm 0.06 \mathrm{a}$ & $0.98 \pm 0.11 \mathrm{a}$ & Haplic alisols \\
\hline
\end{tabular}

Different lowercase letters indicate significant differences among stand types $(p<0.05)$

CR Cryptomeria japonica pure forest, PH-CR Phyllostachys edulis-Cryptomeria japonica mixed forest (Cryptomeria japonica invaded by the bamboo), PH Phyllostachys edulis pure forest

results indicated that $\mathrm{P}$ mineralization (e.g., available $\mathrm{P}$ ) in $\mathrm{CR}$ stands was likely enhanced due to the invasion of moso bamboo. Similarly, Wu et al. (2008) also reported that moso bamboo invasion into broadleaf forests increased available $\mathrm{N}$ and $\mathrm{P}$ concentrations. However, our results on soil total $\mathrm{P}$ concentration contradicted previous studies. For example, Wu et al. (2008) reported that the soil total P did not change after the moso bamboo invaded the adjacent broad-leaves forests in Tianmushan of eastern China. This contradiction may be a result of different litter quality and stand/site conditions between broad-leaved forests (previous studies) and coniferous forests (our study).

However, soil available P in the PH-CR stands showed a much greater seasonal fluctuation, with much lower values observed in June and July, while both CR and PH stand remained relatively stable (Fig. 2). The higher total soil $\mathrm{P}$ along with lower available soil $\mathrm{P}$ during the growing season may be attributed to nutrient return by litter and $\mathrm{P}$ uptake by moso bamboo and other plants (Song et al. 2016, 2017). Given the significantly higher stand density, the large seasonal variation of both litter and dead fine root productions may have contributed to the great seasonal variation of soil total $\mathrm{P}$ observed in this study (Appendix Figs. 4 and 5). Indeed, litter biomass peaked in April or May while dead fine root biomass peaked in June, which provided organic material for the decomposition and nutrient release in June and July. Furthermore, total P concentration in litters and dead fine roots peaked at the middle of the growing season in July, corresponding well to the peak in soil total $\mathrm{P}$ observed.
Fig. 2 Monthly dynamics of total soil $\mathrm{P}$ and available $\mathrm{P}$ concentrations of the three stand types $(n=3)$ sampled at Lushan mountain, China. $C R$ Cryptomeria japonica pure forest, PH-CR Phyllostachys edulisCryptomeria japonica mixed forest, PH Phyllostachys edulis pure forest. N, D, J...represent the abbreviation for each month (From November 2014 to October 2016 (24 months in total)). The bars of this figure presented standard errors

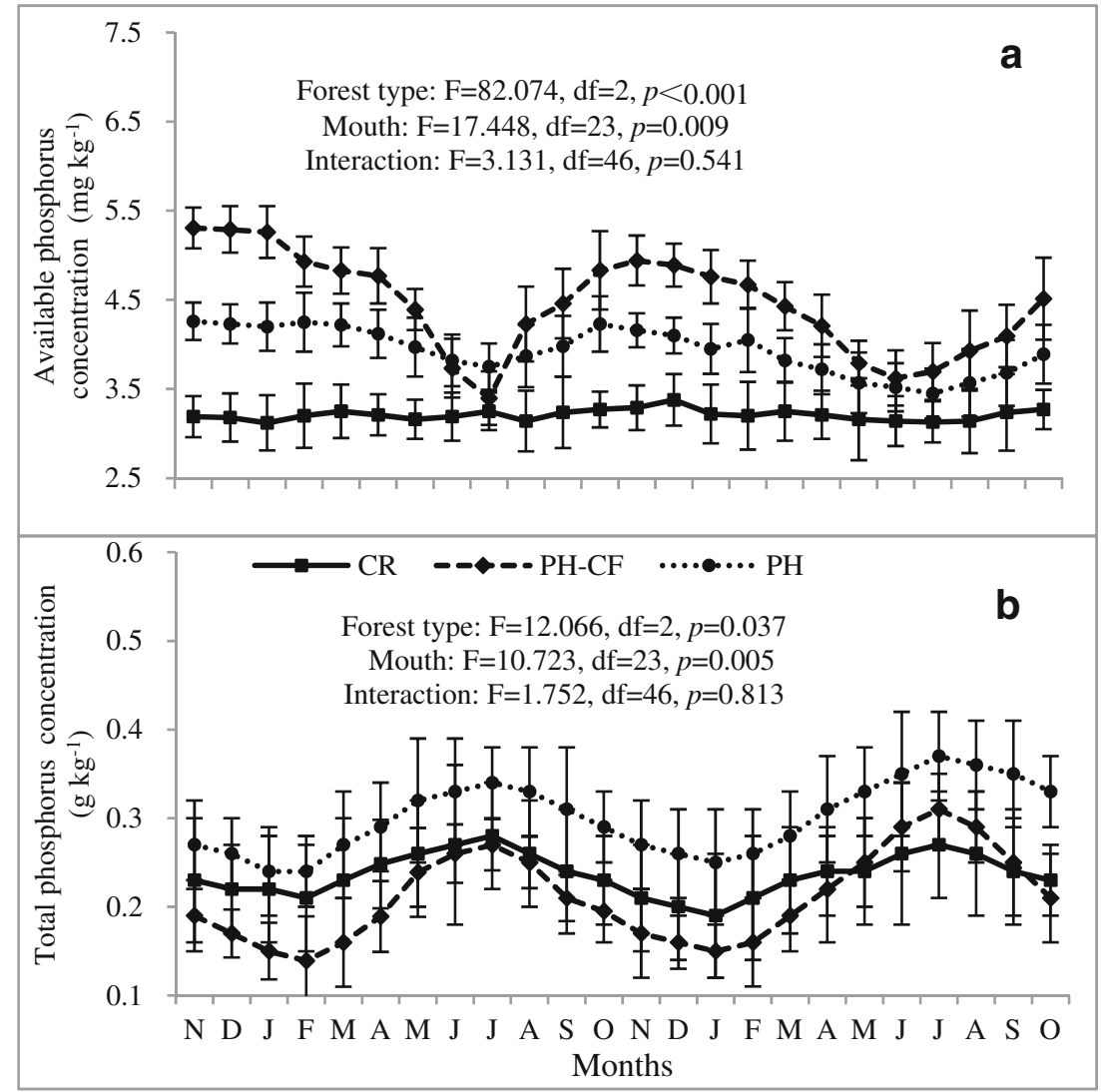


Table 3 Mean total soil $\mathrm{P}$, available $\mathrm{P}, \mathrm{MBP}$, and APA $( \pm \mathrm{SE})$ by stand type

\begin{tabular}{lllll}
\hline Stand type $(n=3)$ & Total P $\left(\mathrm{g} \mathrm{kg}^{-1}\right)$ & $\mathrm{AP}\left(\mathrm{mg} \mathrm{kg}^{-1}\right)$ & APA $\left(\mu \mathrm{mol} p-\mathrm{NP} \mathrm{g}^{-1} \mathrm{~h}^{-1}\right)$ & MBP $\left(\mathrm{mg} \mathrm{kg}^{-1}\right)$ \\
\hline CR & $0.24 \pm 0.05 \mathrm{~b}$ & $3.21 \pm 0.41 \mathrm{~b}$ & $12.34 \pm 2.77 \mathrm{~b}$ & $7.16 \pm 1.12 \mathrm{~b}$ \\
$\mathrm{PH}-\mathrm{CR}$ & $0.21 \pm 0.04 \mathrm{a}$ & $4.42 \pm 0.53 \mathrm{a}$ & $20.92 \pm 3.62 \mathrm{a}$ & $10.83 \pm 2.63 \mathrm{a}$ \\
$\mathrm{PH}$ & $0.30 \pm 0.03 \mathrm{c}$ & $3.93 \pm 0.32 \mathrm{c}$ & $6.01 \pm 1.58 \mathrm{c}$ & $4.76 \pm 1.26 \mathrm{c}$ \\
\hline
\end{tabular}

Different lowercase letters indicate significant differences among stand types $(p<0.05)$

CR Cryptomeria japonica pure forest, $\mathrm{PH}$-CR Phyllostachys edulis-Cryptomeria japonica mixed forest, $\mathrm{PH}$ Phyllostachys edulis pure forest, APA soil acid phosphatase activity, MBP soil microbial biomass phosphorus
Because the increase of soil APA may be an adaptation of plants to a low P environment (Yan et al. 2001), it was not surprising that soil APA increased with decreasing total soil $\mathrm{P}$ concentration due to the invasion of moso bamboo into C. japonica stands. Previous studies reported that soil APA increased in a Carpinus pubescens and Eurycorymbus cavalerei mixed forest (Zhang et al. 2015) as well as in an old-growth monsoon evergreen broadleaf forest and a young Masson pine forest (Zheng et al. 2015) under low $P$ environment.

Similar to soil APA, MBP concentration also increased significantly due to moso bamboo invasion. Although the decrease in total soil $\mathrm{P}$ in the invaded stands had likely contributed to the increase in soil APA and MBP, several other factors were also known to affect soil APA and MBP, including other soil properties, species composition, and management practices (Brookes et al. 1984; Dinkelaker and Marschner 1992; Xu et al. 2002; Tian et al. 2016). In addition to its effect in decreasing total soil $\mathrm{P}$, the invasion of moso bamboo also altered species composition (Table 1 and Appendix Table 4), which, in turn, could affect litter quantity and quality. Previous studies found that species composition significantly affected soil APA (Chen et al. 2016) and MBP (Li et al. 2010). Given that soil MBP is an important source of available $\mathrm{P}$ that directly equilibrates with soil available P, (Zhang 2003) and APA depends on soil available P (Hofmann et al. 2016), the higher concentration of available P observed in PH-CR stands was likely caused by both stand composition and soil conditions altered by moso bamboo invasion.

Soils in tropical and subtropical China are severely deficient in P (Tian et al. 2010; Liu et al. 2013a). Under this selective pressure, native species such as moso bamboo have
Fig. 3 Monthly dynamics of soil microbial biomass phosphorus concentrations and soil acid phosphatase activity of the three stand types $(n=3)$ sampled at Lushan mountain, China. $C R$ Cryptomeriajaponica pure forest, PH-CR Phyllostachys edulisCryptomeria japonica mixed forest, PH Phyllostachys edulis pure forest. N, D, J...represent the abbreviation for each month (from November 2014 to October 2016 (24 months in total)). The bars of this figure presented standard errors

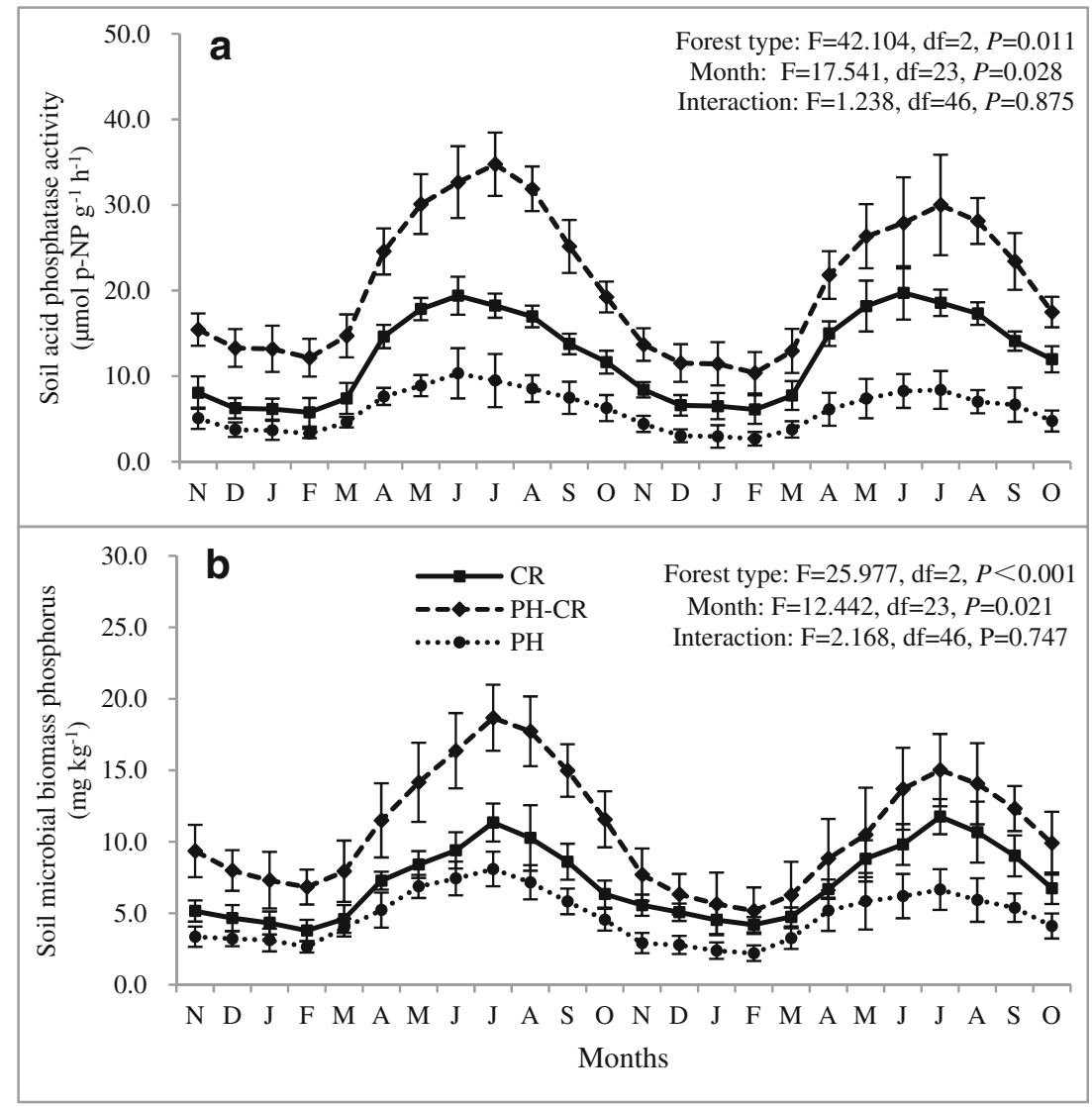


evolved to adapt to low P soils. Our results suggested that moso bamboo increased soil APA when invading into low phosphorus soils in C. japonica stands, resulting in its highefficient $\mathrm{P}$ utilization from low $\mathrm{P}$ environment. One mechanism for moso bamboo to adapt to the lower nutrient environment is to allocate more $\mathrm{C}$ to root growth. A previous study showed that the belowground $\mathrm{C}$ allocation of moso bamboo stands was higher than those in temperate coniferous and mixed forest stands (Isagi et al. 1997). The fine root biomass in evergreen broad-leaves stands that were invaded by bamboo was threefold as high as that of uninvaded stands, suggesting that moso bamboo can greatly increase nutrient uptake by increasing its fine root biomass (Liu et al. 2013b). A recent study also found that the invasion of moso bamboo into a mixed needle- and broad-leaved forest resulted in increases of root biomass, special root length, and lateral roots (Shen et al. 2016).

C. japonica is an exotic tree species introduced to Lushan (Liang et al. 2014), where its plantations have been facing many problems, including low species diversity, simplified structure (monoculture with a poorly developed shrub and herb layer), and poor resistance to natural disturbances (Wan et al. 2008). For example, many C. japonica stands had been severely damaged during the 2008 snow storm. Therefore, the invasion of moso bamboo into $C$. japonica stands may have some significant ecological benefits, such as increasing species diversity, enhancing stand structure (Table 1 and Appendix Table 4), and improving soil properties (unpublished data). Even if the invasion resulted in the eventual establishment of pure moso bamboo stands, it would still support a better species biodiversity than $C$. japonica pure stands (Appendix Table 4). Therefore, the invasion of moso bamboo into exotic $C$. japonica plantation may be encouraged at Lushan, especially considering that Lushan is a mountain with both biological and cultural significance.

Our study used a natural experiment approach to investigate the ecological consequence of moso bamboo invasion, focusing on soil P status and dynamics. We selected three similar sites each included a pure $C$. japonica stand, a pure moso bamboo stand, and a stand resulted from the invasion of moso bamboo into the pure C. japonica stand in the middle. Although we were unable to collect preinvasion soil data to demonstrate the similarity in soil conditions before the invasion, the mixed stands in our study were created due to the invasion of moso bamboo into $C$. japonica plantation. Given the immediate adjacency of the three studied stand types, it sounds reasonable to assume that the soil conditions would be rather similar among the three stand types at each location, at least between the pure $C$. japonica stand and the mixed stand, prior to the invasion. Therefore, we believe that the invasion of moso bamboo was largely responsible for the altered soil $\mathrm{P}$ status and dynamics observed in our study.
The increased soil available P (this study) and N ( $\mathrm{Li}$ et al. 2017a) due to the invasion by moso bamboo could further promote the invasion of moso bamboo into $C$. japonica stands, which may partly explain the accelerated expansion of moso bamboo observed across its native range.

Our study indicated that moso bamboo invasion resulted in a favorable condition for the decomposition of the mixed moso bamboo and CR litter and dead fine roots. Fast decomposition of organic matter likely caused a decline in the soil total $\mathrm{P}$ concentration, but an increase in soil available $\mathrm{P}$ concentration in $\mathrm{PH}-\mathrm{CR}$ stand. These changes would promote the activity of APA, which could further increase soil available $P$ concentration. Also, the activation of soil $\mathrm{P}$ could promote microbial activities, further increasing the concentration of MBP. Given that $\mathrm{P}$ is the most limiting nutrient, the observed changes in soil $\mathrm{P}$ dynamics due to moso bamboo invasion would significantly alter the composition, structure, and function of the invaded forests in subtropical China.

\section{Conclusion}

The invasion of moso bamboo (P. edulis) into neighboring $C$. japonica plantations significantly altered soil $\mathrm{P}$ status and dynamics. Soil available P concentration, soil acid phosphatase activity (APA), and soil microbial biomass phosphorus (MBP) concentration were significantly higher while soil total P concentration was significantly lower in moso bamboo-invaded stands compared to their adjacent pure stands of either moso bamboo or C. japonica. The increase in soil available $\mathrm{P}$ suggested that the invasion of moso bamboo promoted $\mathrm{P}$ mineralization while the increase in APA suggested that the invasion also resulted in higher P use efficiency.

Acknowledgements We are grateful to the Lushan Mountain National Forest Ecological Station for providing the study sites. This study was financially supported by the Strategic Priority Research Program of the Chinese Academy of Sciences (Grant No. XDA05050205), National Natural Science Foundation of China (31460185), Gan-Po 555 Talent Project Funding of Jiangxi Province, the Innovation Fund Designated for Graduate Students of Jiangxi Province (YC2016-B037), and CFERN \& GENE award funds on ecological papers. We thank Dr. Evan Siemann of Rice University, two anonymous reviewers, and the Chief Editor and Handling Editor of the journal for their suggestions on improving the manuscript.

Data availability The datasets generated during the current study are available from the corresponding authors on reasonable request.

\section{Compliance with ethical standards}

Conflicts of interest The authors declare that they have no conflict of interest. 


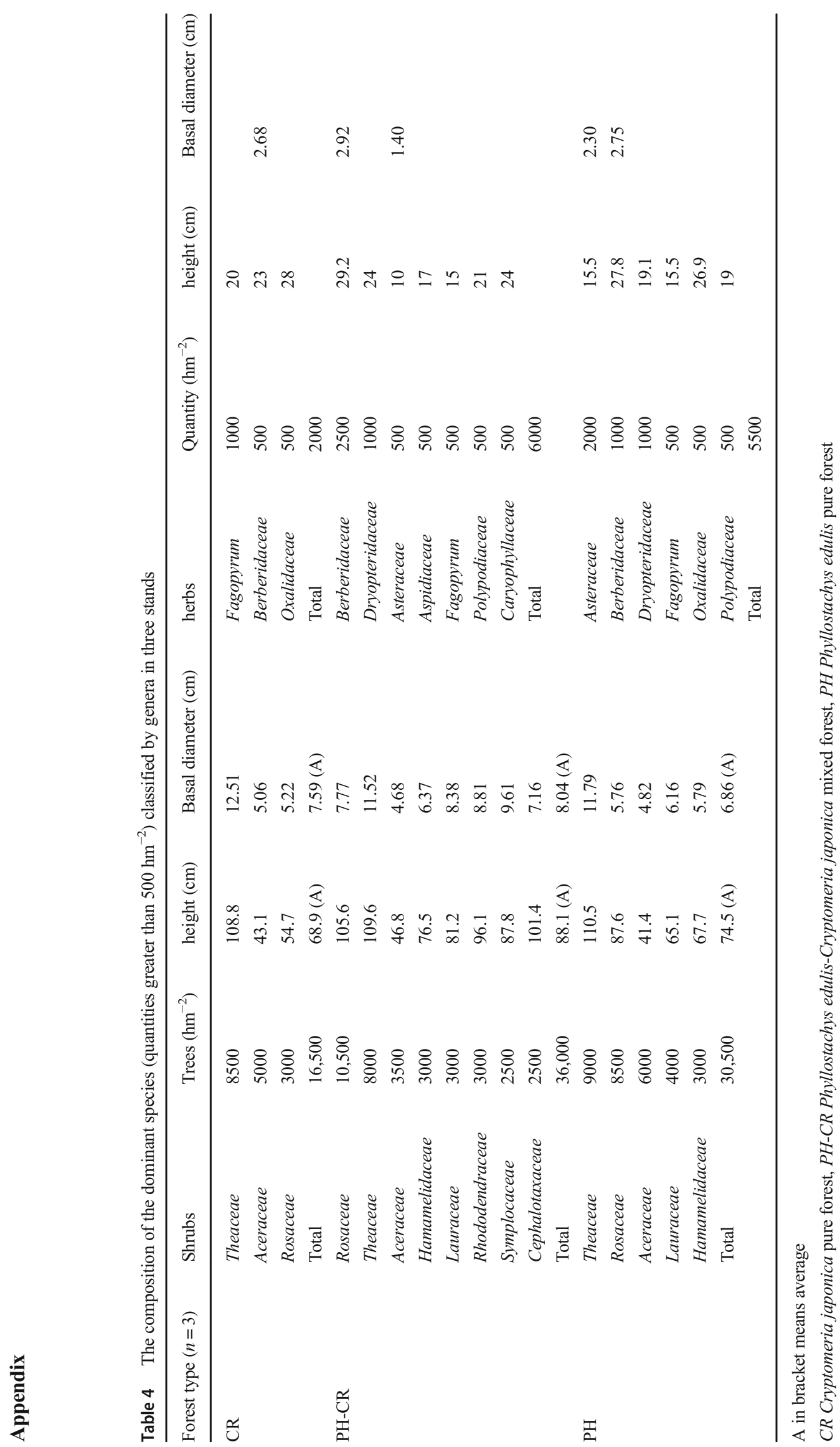




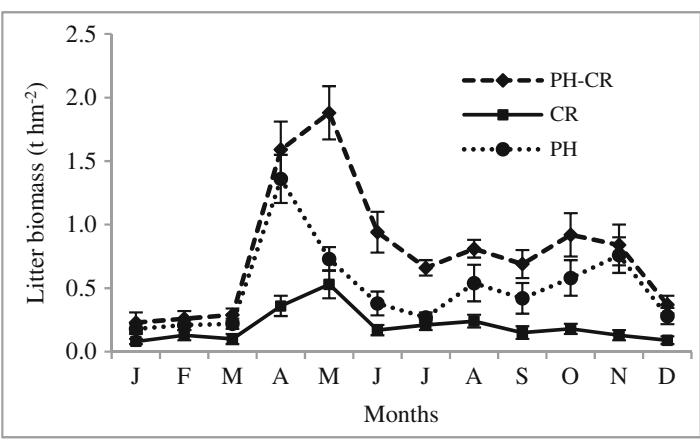

Fig. 4 Monthly dynamics of litter biomass and total P concentration for the three stand types $(n=3)$ sampled at Lushan mountain, China. $C R$ Cryptomeria japonica pure forest, PH-CR Phyllostachys edulisCryptomeria japonica mixed forest, $P H$ Phyllostachys edulis pure forest. N, D, J...represent the abbreviation for each month (from

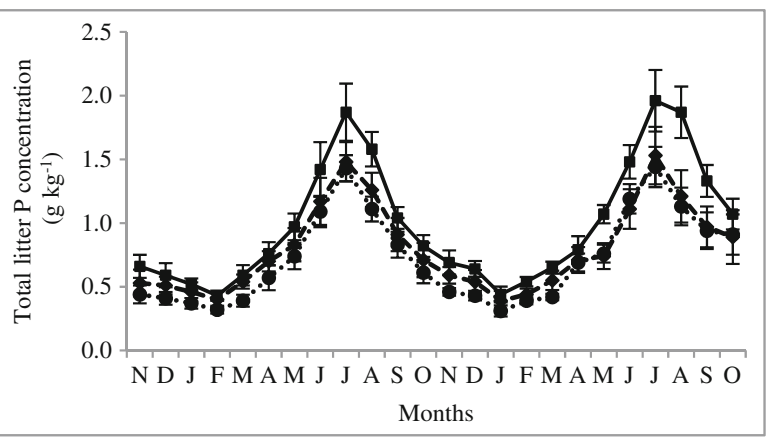

November 2014 to October 2016 (24 months in total)). J, F, M... represent the abbreviation for each month (from January 2015 to December 2015 (12 months in total)). The bars of this figure presented standard errors

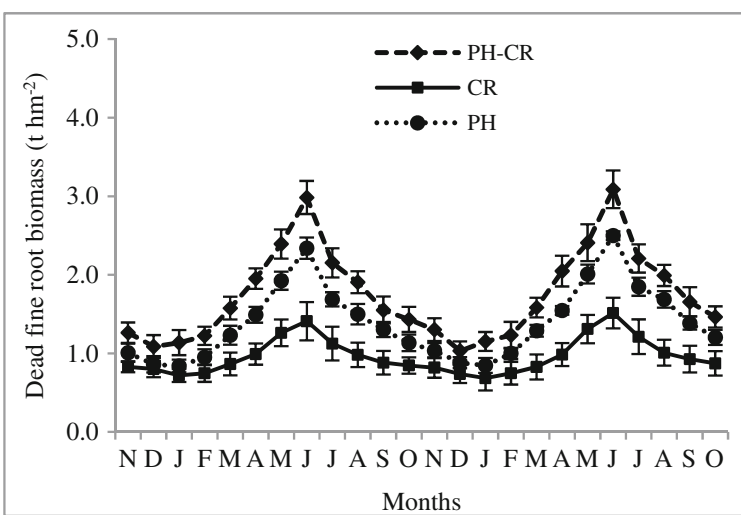

Fig. 5 Monthly dynamics of dead fine root biomass and total $\mathrm{P}$ concentration of the three stand types $(n=3)$ sampled at Lushan mountain, China. CR Cryptomeria japonica pure forest, $P H-C R$ Phyllostachys edulis-Cryptomeria japonica mixed forest, $P H$

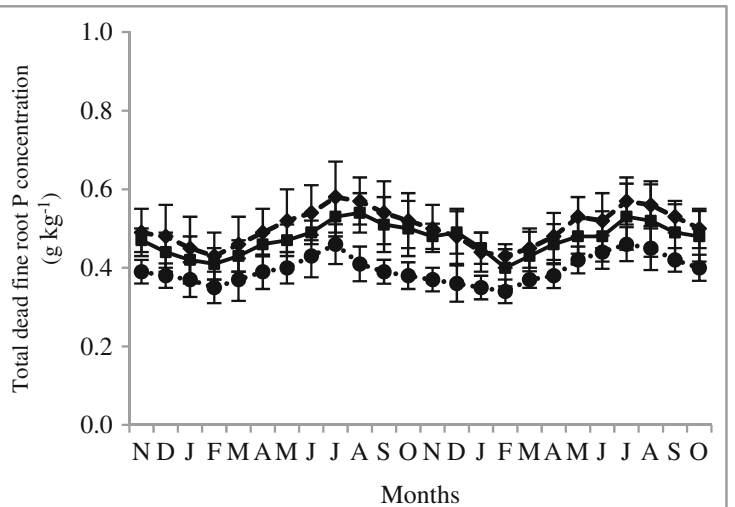

Phyllostachys edulis pure forest. N, D, J...represent the abbreviation for each month (from November 2014 to October 2016 (24 months in total)). The bars of this figure presented standard errors

\section{References}

Bai S, Conant RT, Zhou G, Wang Y, Wang N, Li Y, Zhang K (2016) Effects of moso bamboo encroachment into native, broad-leaved forests on soil C and nitrogen pools. Sci Rep 6(1):31480. https:// doi.org/10.1038/srep31480

Brookes PC, Powlson DS, Jenkinson DS (1984) Phosphorus in the soil microbial biomass. Soil Biol Biochem 16(2):169-175. https://doi. org/10.1016/0038-0717(84)90108-1

Chang EH, Chiu CY (2015) Changes in soil microbial community structure and activity in a cedar plantation invaded by moso bamboo. Appl Soil Ecol 91:1-7. https://doi.org/10.1016/j.apsoil.2015.02.001

Chen L, Zhang C, Duan W (2016) Temporal variations in phosphorus fractions and phosphatase activities in rhizosphere and bulk soil during the development of Larix olgensis plantations. J Plant Nutr Soil Sci 179(1):67-77. https://doi.org/10.1002/jpln.201500060

D’Angelo E, Crutchfield J, Vandiviere M (2001) Rapid, sensitive, microscale determination of phosphate in water and soil. J Environ Qual 30(6):2206-2209. https://doi.org/10.2134/jeq2001.2206

Deng MF, Liu LL, Sun ZZ, Piao SL, Ma YC, Chen YW, Wang J, Qiao CL, Wang X, Li P (2016) Increased phosphate uptake but not resorption alleviates phosphorus deficiency induced by nitrogen deposition in temperate Larix principis-rupprechtii plantations. New Phytol 212(4):1019-1029. https://doi.org/10.1111/nph.14083

Dinkelaker B, Marschner H (1992) In vivo demonstration of acid phosphatase activity in the rhizosphere of soil-grown plants. Plant Soil 144(2):199-205. https://doi.org/10.1007/BF00012876

Elser JJ, Bracken MES, Cleland EE, Gruner DS, Harpole WS, Hillebrand H, Ngai JT, Seabloom EW, Shurin JB, Smith JE (2007) Global analysis of nitrogen and phosphorus limitation of primary producers in freshwater, marine and terrestrial ecosystems. Ecol Lett 10(12): 1135-1142. https://doi.org/10.1111/j.1461-0248.2007.01113.x

Fukushima K, Usui N, Ogawa R, Tokuchi N (2015) Impacts of moso bamboo (Phyllostachys pubescens) invasion on dry matter and $\mathrm{C}$ and nitrogen stocks in a broad-leaved secondary forest located in Kyoto, western Japan. Plant Spec Biol 30(2):81-95. https://doi.org/ 10.1111/1442-1984.12066

Hofmann K, Heuck C, Spohn M (2016) Phosphorus resorption by young beech trees and soil phosphatase activity as dependent on phosphorus availability. Oecologia 181(2):369-379. https://doi.org/10.1007/ s00442-016-3581-x

Ikegami N, Satake T, Nagayama Y, Inubushi K (2014) Changes in silica in litterfall and available silica in the soil of forests invaded by 
bamboo species (Phyllostachys pubescens and P. bambusoides) in western Japan. Soil Sci Plant Nutr 60(5):731-739. https://doi.org/ 10.1080/00380768.2014.942794

Isagi Y, Kawahara K, Ito H (1997) Net production and C cycling in a bamboo Phyllostachys pubescens stand. Plant Ecol 130(1):41-52. https://doi.org/10.1023/A:1009711814070

Jia ZB (2009) China forest resources report-Seventh National Forest Resource Inventory. China Forestry Publishing House, Beijing (In Chinese with English Abstract)

Lampurlanés J, Cantero-Martinez C (2003) Soil bulk density and penetration resistance under different tillage and crop management systems and their relationship with barley root growth. Agron J 95(3): 526-536. https://doi.org/10.2134/agronj2003.0526

Li Y, Zhang JC, Pan SH (2010) Study on the soil microbial biomass P of coastal protective forest in Shanghai. Chin Forest Sci Tech 24:65-70 (In Chinese with English Abstract)

Li Z, Zhang L, Deng B, Liu Y, Kong F, Huang G, Zou Q, Liu Q, Guo X, $\mathrm{Fu}$ Y, Niu D, Siemann E (2017a) Effects of moso bamboo (Phyllostachys edulis) invasions on soil nitrogen cycles depend on invasion stage and warming. Environ Sci Pollut Res 24(32):24989 24999. https://doi.org/10.1007/s11356-017-0186-9

Li Y, Li YF, Chang SX, Xu Q, Guo Z, Gao Q, Qin Z, Yang F, Liang X (2017b) Bamboo invasion of broadleaf forests altered soil fungal community closely linked to changes in soil organic $\mathrm{C}$ chemical composition and mineral N production. Plant Soil 418(1-2):507521. https://doi.org/10.1007/s11104-017-3313-y

Liang TJ, Li XH, Zou Q, Zong DS, Zong DH (2014) Investigation and utilization of some native plant resources in Lushan district. Northern Hortic 5:72-77 (In Chinese with English Abstract)

Lin YT, Tang SL, Pai CW, Whitman WB, Coleman DC, Chiu CY (2014) Changes in the soil bacterial communities in a cedar plantation invaded by moso bamboo. Microb Ecol 67(2):421-429. https://doi. org/10.1007/s00248-013-0291-3

Liu GS (1996) Soil physical and chemical analysis and description of cross-section. China Standard Press, Beijing (In Chinese with English Abstract)

Liu X, Wang L (2010) Scientific survey and study of biodiversity on the Lushan Nature Reserve in Jiangxi province. Science Press, Beijing (In Chinese with English Abstract)

Liu XJ, Duan L, Mo JM, Du EZ, Shen JL, Lu XK, Zhang Y, Zhou XB, He CN, Zhang FS (2011) Nitrogen deposition and its ecological impact in China: an overview. Environ Pollut 159(10):2251-2264. https:// doi.org/10.1016/j.envpol.2010.08.002

Liu JX, Huang WJ, Zhou GY, Zhang DQ, Liu SZ, Li YY (2013a) Nitrogen to phosphorus ratios of tree species in response to elevated $\mathrm{C}$ dioxide and nitrogen addition in subtropical forests. Glob Chang Biol 19(1):208-216. https://doi.org/10.1111/gcb.12022

Liu J, Yang QP, Song QN, Yu DK, Yang GY, Qi HY, Shi JM (2013b) Strategy of fine root invasion of Phyllostachys pubescens population into evergreen broad-leaves forest. Chin J Plant Ecol 37(3):230 238. (In Chinese with English Abstract). https://doi.org/10.3724/ SP.J.1258.2013.00023

Lu RK (1999) Analysis methods of soil science and agricultural chemistry. Agricultural Science and Technology Press, Beijing (In Chinese with English Abstract)

Mertens B, Liu H, Belcher B, Ruiz-Pérez M, Fu MY, Yang XS (2008) Spatial patterns and processes of bamboo invasion in Southern China. Appl Geogr 28(1):16-31. https://doi.org/10.1016/j.apgeog. 2007.07.012

Nelson DW, Sommers LF (1975) A rapid and accurate method for estimating organic carbon in soil. PIAS 84:456-462

Qin H, Niu L, Wu Q, Chen J, Li Y, Liang C, Xu Q, Fuhrmann J, Shen Y (2017) Bamboo forest expansion increases soil organic carbon through its effect on soil arbuscular mycorrhizal fungal community and abundance. Plant Soil 420:1-15
Sharma M, Parton J (2007) Height-diameter equations for boreal tree species in Ontario using a mixed-effects modeling approach. For Ecol Manag 249(3):187-198

Schneider K, Turrión MB, Gallardo JF (2000) Modified method for measuring acid phosphatase activities in forest soils with high organic matter content. Commun Soil Sci Plan 31(19-20):3077-3088. https://doi.org/10.1080/00103620009370651

Shen R, Bai SB, Zhou GM, Wang YX, Wang N, Wen GS, Chen J (2016) The response of root morphological plasticity to the invasion of a population of Phyllostachys edulis into a mixed needle-and broadleaved forest. Acta Ecol Sinica 36:326-334 (In Chinese with English Abstract)

Shiau YJ, Chiu CY (2017) Changes in soil biochemical properties in a cedar plantation invaded by moso bamboo. Forests 8(7):222. https:// doi.org/10.3390/f8070222

Shinohara Y, Otsuki K (2015) Comparisons of soil-water content between a moso bamboo (Phyllostachys pubescens) forest and an evergreen broadleaved forest in western Japan. Plant Spec Biol 30(2):96-103. https://doi.org/10.1111/1442-1984.12076

Song QN, Ouyang M, Yang QP, Lu H, Yang GY, Chen FS, Shi JM (2016) Degradation of litter quality and decline of soil nitrogen mineralization after moso bamboo (Phyllostachys pubscens) invasion to neighboring broadleaved forest in subtropical China. Plant Soil 404(1-2): 113-124. https://doi.org/10.1007/s11104-016-2835-z

Song QN, Lu H, Liu J, Yang J, Yang GY, Yang QP (2017) Accessing the impacts of bamboo expansion on NPP and N cycling in evergreen broadleaved forest in subtropical China. Sci Rep 7:40383. https:// doi.org/10.1038/srep40383

Suzuki S (2015) Chronological location analyses of giant bamboo (Phyllostachys pubescens) groves and their invasive invasion in a satoyama landscape area, western Japan. Plant Spec Biol 30(1):6371. https://doi.org/10.1111/1442-1984.12067

Tian H, Chen G, Zhang C, Melillo JM, Hall CA (2010) Pattern and variation of $\mathrm{C}: \mathrm{N}$ : $\mathrm{P}$ ratios in China's soils: a synthesis of observational data. Biogeochemistry 98(1-3):139-151. https://doi.org/10. 1007/s10533-009-9382-0

Tian J, Wei K, Condron LM, Chen Z, Xu Z, Chen L (2016) Impact of land use and nutrient addition on phosphatase activities and their relationships with organic phosphorus turnover in semi-arid grassland soils. Biol Fert Soils 52(5):675-683. https://doi.org/10.1007/ s00374-016-1110-z

Umemura M, Takenaka C (2015) Changes in chemical characteristics of surface soils in hinoki cypress (Chamaecyparis obtusa) forests induced by the invasion of exotic Moso bamboo (Phyllostachys pubescens) in central Japan. Plant Spec Biol 30(1):72-79. https:// doi.org/10.1111/1442-1984.12038

Wan HL, Feng ZW, Pang HD (2008) On the exotic plants in Lushan, Jiangxi Province, China. Acta Ecol Sin 28:103-110 (In Chinese with English Abstract)

Wang B, Wang D, Niu X (2013) Past, present and future forest resources in China and the implications for $\mathrm{C}$ sequestration dynamics. J Food Agric Environ 11:801-806

Wang YX, Bai SB, Binkley D, Zhou GM, Fang FY (2016a) The independence of clonal shoot's growth from light availability supports moso bamboo invasion of closed-canopy forest. Forest Ecol Manag 368:105-110. https://doi.org/10.1016/j.foreco.2016.02.037

Wang X, Sasaki A, Toda M, Nakatsubo T (2016b) Changes in soil microbial community and activity in warm temperate forests invaded by moso bamboo (Phyllostachys pubescens). J Forest Res 21(5): 235-243. https://doi.org/10.1007/s10310-016-0533-6

Wu JS, Jiang PK, Wang ZL (2008) The effects of Phyllostachys pubescens invasion on soil fertility in Nation Reserve of Mount Tianmu. Acta Agric Jiangxi 30:689-692 (In Chinese with English Abstract)

Xu YC, Shen QR, Ran W (2002) Effects of zero-tillage and application of manure on soil microbial biomass $\mathrm{C}, \mathrm{N}$ and $\mathrm{P}$ after sixteen years of 
cropping. Acta Pedol Sin 39:89-96 (In Chinese with English Abstract)

Xu QF, Jiang PK, Wu JS, Zhou GM, Shen RF, Fuhrmann JJ (2015) Bamboo invasion of native broadleaf forest modified soil microbial communities and diversity. Biol Invasions 17(1):433-444. https:// doi.org/10.1007/s10530-014-0741-y

Yan XL, Liao H, Trull MC, Steve E, Beebe SE, Lynch JP (2001) Induction of a major leaf acid phosphatase does not confer adaptation to low phosphorus availability in common bean. Plant Physiol 125(4):1901-1911. https://doi.org/10.1104/pp.125.4.1901

Ying W, Jin JX, Jiang H, Zhang XY, Lu XH, Chen XF, Zhang JM (2016) Satellite-based detection of bamboo invasion over the past 30 years in Mount Tianmushan, China. Int J Remote Sens 37(13):2908 2922. https://doi.org/10.1080/01431161.2016.1186851
Zhang SR (2003) Temporal-spatial variability of soil available phosphorus and potassium in the alluvial region of the Huang-Huai-Hai plain. Plant Nutr Fertil Sci 9:3-8

Zhang C, Xie G, Fan S, Zen L (2010) Variation in vegetation structure and soil properties, and the relation between understory plants and environmental variables under different Phyllostachys pubescens forests in southeastern China. Environ Manag 45(4):779-792. https://doi.org/10.1007/s00267-010-9429-y

Zhang XM, Hong K, Yi Y (2015) Effect of short-term phosphate starvation on acid phosphatase activity of Carpinus pubescens and Eurycorymbus cavalerei. Russ J Plant Physiol 62(1):57-64. https:// doi.org/10.1134/S1021443715010185

Zheng M, Huang J, Chen H, Wang H, Mo J (2015) Responses of soil acid phosphatase and beta-glucosidase to nitrogen and phosphorus addition in two subtropical forests in southern China. Eur J Soil Biol 68: 77-84. https://doi.org/10.1016/j.ejsobi.2015.03.010 